\title{
TINJAUAN HUKUM BAGI KREDITOR ATAS UTANG PIUTANG DENGAN JAMINAN HAK ATAS TANAH
}

\author{
Wiedtriana Putri Setyaningtyas Ratnasari \\ E-mail: wiedtrianaputri@gmail.com \\ Mahasiswa Fakultas Hukum Universitas Sebelas Maret \\ Ambar Budhisulistyawati \\ E-mail: ambarbudhi@gmail.com \\ Dosen Fakultas Hukum Universitas Sebelas Maret
}

\begin{abstract}
This article has aims to know legal protection and dispute resolution for creditor about land guarantee that has been not registered as a Mortage rights. This research was categorized as doctrinal research and prespective though which means writer will give argumentation to know and ensure the problem solving over this research. The data used by writers which are primary legal material and secondary legal material, one of them is based on Law Number 4 year 1996 about Mortgage. Material techniques collect did by library search which means riset, seek for reference which relevant to this research. This research approach by some of the constitution and used to concern legislation and regulation. Material data analysis used to deductive thinking scheme. These results shows if legal protection to creditor about land guarantee that has not registered as a Mortage rights can't be used as guarantee in their agreement between creditor and debitor. This was happened because the guarantee has not been registered as Mortage Rights, and for creditor that didn't hold Mortgage Certificate the legal protection isn't covered by the Regulation though. Legal protection that can used refers to Article 11 Kitab UndangUndang Hukum Perdata, mentions that all of debitor wealth included moveable property either not, even wealth that will appear in the future used as a guarantee. Second, dispute resolutions didn't mention a more detail in their agreement. Clausule on the agreement just mention about deliberation, but it can't help to finished the dispute between both of them. Thus, writers had an argumentation if dispute resolution finished by lawsuit at court.
\end{abstract}

Keywords: Land Guarantee; Legal Protection; Dispute Resolution

\begin{abstract}
Abstrak
Penulisan hukum ini bertujuan untuk mengetahui perlindungan hukum dan penyelesaian bagi kreditor atas jaminan hak atas tanah yang tidak didaftarkan sebagai hak tanggungan. Penelitian ini merupakan penelitian hukum normatif yang bersifat perspektif, yaitu penulis akan memberikan argumentasi guna menjawab rumusan masalah. Jenis bahan hukum meliputi bahan hukum primer dan bahan hukum sekunder, salah satunya adalah Undang-Undang Nomor 4 Tahun 1996 tentang Hak Tanggungan. Teknik pengumpulan bahan dilakukan dengan cara studi pustaka, yaitu mengkaji, membaca buku-buku atau sumber yang relevan dengan penulisan hukum ini. Pendekatan penelitian ini melalui pendekatan perundang-undangan yang akan menggunakan legislasi dan regulasi. Teknik analisis data yang digunakan menggunakan pola berpikir deduktif. Hasil penelitian menunjukkan bahwa perlindungan hukum bagi kreditor atas jaminan tanah yang tidak didaftarkan sebagai hak tanggungan ini kreditor tidak bisa menggunakan jaminan tanah tersebut karena kreditor tidak memegang Sertifikat Hak Tanggungan, perlindungan hukum yang diberikan adalah mengacu pada Pasal 1131 Kitab Undang-Undang Hukum Perdata bahwa jaminan yang dipakai adalah seluruh kekayaan debitor baik benda bergerak maupun tidak bergerak, baik yang sudah ada maupun yang akan timbul di kemudian hari. Selanjutnya, penyelesaian sengketa para pihak juga tidak bisa diselesaikan apabila berpacu pada perjanjian hutang piutang, karena pada perjanjian tersebut hanya menyebutkan penyelesaian perselisihan melalui musyawarah mufakat. Namun, pada saat musyawarah mufakat kedua belah pihak tidak mencapai titik temu. Maka penulis berpendapat bahwa penyelesaian dilakukan melalui gugatan wanprestasi.
\end{abstract}

Kata Kunci: Jaminan Hak Atas Tanah, Perlindungan Hukum; Penyelesaian Sengketa 


\section{A. Pendahuluan}

Jaminan Hak Atas Tanah atau Hak Tanggungan sebagaimana yang diatur dalam UndangUndang Nomor 4 Tahun 1996 tentang Hak Tanggungan menjadi sangat penting keberadaannya karena ditujukan untuk menjamin kepastian hukum kepada pemberi dan penerima hak tanggungan sekaligus untuk memberikan perlindungan hukum yang mungkin suatu saat salah satu pihak mengadakan tindakan yang merugikan pihak lainnya. Contohnya ketika pemberi Hak Tanggungan tidak mampu membayar utang kepada kreditor, maka dengan adanya hak tanggungan, pemegang hak tanggungan mempunyai kekuatan hukum yang kuat untuk mendapatkan pembayaran atas piutang debitor dengan cara mengeksekusi tanah yang menjadi jaminan dan telah dibebankan Hak Tanggungan (Niken Saraswati, 2018:2). Kepala Sertifikat Hak Tanggungan dengan irahirah "Demi Keadilan Berdasarkan Ketuhanan Yang Maha Esa" ini menegaskan bahwa sertifikat memiliki kekuatan eksekutorial. Sehingga, apabila debitor cidera janji maka pemegang Sertifikat Hak Tanggungan dapat langsung melakukan eksekusi atas Hak Tanggungan yang kedudukannya sesuai dengan putusan pengadilan. (Ignatius Ridwan, 1996: 45) tanpa harus mengajukan gugatan ke pengadilan atau parate eksekusi. (Tampubolon, https://konsultanhukum.web.id/prosedurpembebanan-hak-tanggungan-hak-atas-tanah/Diakses pada 30 September 2019 )

Jaminan Hak Atas Tanah yang telah didaftarkan sebagai Hak Tanggungan tentunya akan memperoleh kepastian mengenai kepastian mengenai kedudukan yang diutamakan, dan tentunya apabila debitor cidera janji kreditor dapat melakukan pelelangan umum atas Hak Tanggungan yang menjadi jaminan atas utang. Lahirnya perjanjian utang piutang yang penulis teliti, bermula pada kesepakatan para pihak untuk sama-sama mengikatkan diri pada perjanjian pada tanggal 18 Februari 2015. Alasan debitor berhutang ini dikarenakan hendak membuka suatu usaha di Kalimantan, maka butuh modal sebanyak Rp100.000.000,- (Seratus juta rupiah) yang ia dapatkan pinjamannya dari kreditor. Pada perjanjian tersebut, telah diatur beberapa klausula mengenai hak dan kewajiban, besaran angsuran, jumlah dan penyerahan pinjaman, jaminan hutang, penyelesaian perselisihan, dan penutup. Jaminan yang diberikan oleh debitor ini berupa Sertifikat Hak Milik No. $127 \mathrm{X}$ yang terletak di Karanglesem, Purwokerto seluas $120 \mathrm{~m}^{2}$ sebagai jaminan hutang tersebut. Tetapi, jaminan hak atas tanah ini tidak didaftarkan sebagai Hak Tanggungan oleh para pihak. Perjanjian mengenai jaminan tidak dipisahkan menjadi perjanjian accesoir, keberadaan jaminan menjadi 1 (Satu) kesatuan dengan perjanjian pokok yaitu perjanjian hutang piutang.

Permasalahan bermula pada saat debitor wanprestasi tidak membayar angsuran sejak bulan ke-13 yaitu nominal yang dibayarkan tidak sesuai seperti yang diperjanjikan. Debitor membayar angsuran sejumlah Rp3.000.000,- yang seharusnya Rp5.000.000,-. Pada bulan ke-14 dan ke-15, debitor sama sekali tidak melakukan pelunasan hutang dan dapat dikatakan sebagai wanprestasi. Selama bulan ke-14 dan ke-15 tersebut, debitor mengirim somasi berupa teguran tertulis sebanyak 2 (Dua) kali agar segera melakukan pelunasan hutang. Musyawarah mufakat yang dilakukan para pihak juga tidak mencapai titik temu, maka kreditor mengajukan eksekusi atas Sertifikat Hak Milik (SHM) yang digunakan sebagai jaminan hutang. Namun, kreditor tidak bisa mengajukan permohonan eksekusi ke pengadilan dan/atau melakukan pelelangan umum lalu mengambil pelunasan hutang tanah tersebut. Pada saat kreditor mengajukan permohonan eksekusi, pengadilan menolak dengan alasan kreditor tidak memiliki Sertifikat Hak Tanggungan.

Berdasarkan uraian tersebut di atas, perlindungan hukum tidak bisa diberikan bagi kreditor oleh Undang-Undang Hak Tanggungan karena tanah yang tidak didaftarkan tidak diakomodir oleh perjanjian ini. Hal inilah yang akan dikaji oleh penulis dalam tulisan hukum.

\section{B. Metode Penelitian}

Penulis menggunakan metode penelitian normatif atau doctrinal. Sifat penelitian ini bersifat perspektif yang dimaksudkan untuk memberikan argumentasi untuk menyelesaikan masalah dan apa yang harus dilakukan. (Marzuki, 2014: 55-56). Pendekatan penelitian yang digunakan adalah menggunakan pendekatan peraturan perundang-undangan, yaitu melalui legislasi dan regulasi. Sumber bahan hukum yang digunakan adalah bahan hukum primer dan bahan hukum sekunder. Teknik pengumpulan data yang dilakukan adalah melalui studi pustaka. 


\title{
C. Hasil Penelitian dan Pembahasan
}

Dari sudut pandang Hukum Tata Negara (HTN), Perlindungan hukum merupakan suatu perkembangan dari konsep pengakuan dan perlindungan setiap hak-hak asasi manusia (HAM) yang telah berkembang sejak abad ke-19. Konsep mengenai perlindungan hukum ini adalah dengan adanya pembatasan dan peletakan kewajiban kepada masyarakat dan pemerintah yang dituangkan dalam bentuk peraturan perundang-undangan. Menurut Satjipto Rahardjo, perlindungan hukum adalah suatu upaya untuk mengkoordinasikan berbagai kepentingan dalam masyarakat supaya tidak terjadi tumpang tindih dan dapat menikmati semua hak-hak yang diberikan oleh hukum (Luthvi Febryka, 2016: 39-40). Perlindungan hukum menurut Wiryono Prodjodikoro, yakni suatu upaya perlindungan yang diberikan kepada subyek hukum tersebut untuk melindungi hak dan kepentingan mereka. (Lidya Mahendra, 2016: 269)

Munculnya teori mengenai perlindungan hukum ini berasal dari tujuan hukum itu sendiri yaitu untuk mengintegrasikan dan mengkoordinasikan berbagai kepentingan baik masyarakat maupun pemerintah dengan cara mengatur perlindungan dan pembatasan berbagai kepentingan tersebut. Perlindungan hukum sendiri sejatinya dibagi menjadi 2 (dua), yaitu; perlindungan hukum preventif dan represif. Perlindungan hukum secara preventif adalah perlindungan hukum yang diberikan berupa pencegahan terjadinya sengketa, sedangkan perlindungan hukum secara represif adalah perlindungan hukum yang diberikan dengan tujuan untuk menyelesaikan sengketa. (Philipus M. Hadjon, 1987: 2).

Berdasarkan uraian di atas, perlindungan hukum merupakan suatu bentuk perlindungan yang diberikan kepada subjek hukum baik individu (perorangan), badan hukum, atau pemerintah selaku pembentuk Undang-Undang yang berkaitan dengan hak dan kewajiban bagi setiap subjek hukum baik bersifat represif maupun preventif, perlindungan hukum juga dapat diartikan sebagai perlindungan yang diberikan oleh aparat penegak hukum untuk memberikan rasa aman, baik secara pikiran maupun gangguan dan berbagai ancaman dari pihak manapun.

Apabila berbicara mengenai subjek hukum, subjek hukum memiliki peran yang penting dalam keperdataan karena setiap subjek hukum memiliki wewenang hukum. Dalam hukum perdata, mengenal subjek hukum sebagai salah satu konsep yang tidak dapat dipisahkan, karena subjek hukum merupakan konsep dan pengertian yang mendasar. (Rosnindar Sembiring, 2016: 82)

Orang (person) sebagai subjek hukum dibedakan menjadi 2 (dua) hal:

a. Orang (Natuurlijke Persoon), dalam bentuk manusia secara pribadi

b. Badan Hukum (Rechts Persoon), orang dalam bentuk badan hukum atau orang yang diciptakan hukum secara fiksi (persona ficta)

Pada perjanjian yang penulis teliti, subjek hukum dari para pihak adalah Orang, karena para pihak berlaku atas nama diri sendiri untuk mengadakan perjanjian tanpa mewakili badan hukum manapun. Hal ini dapat dibuktikan dari komparasi perjanjian dengan para pihak sebagai berikut:

1. Pihak Pertama sebagai Penerima Pinjaman (Debitor)

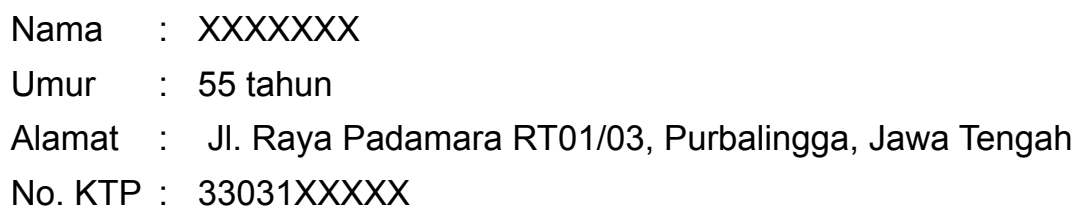

2. Pihak Kedua sebagai Pemberi Pinjaman (Kreditor)

\author{
Nama : XXXXXXX \\ Umur : 58 tahun \\ Alamat : Jl. Jend. Gatot Subroto, Purwokerto, Jawa Tengah \\ No. KTP : 33031560XXXX
}


Selanjutnya mengenai objek dan bentuk perjanjian. Sesuai dengan Pasal 1320 Kitab UndangUndang Hukum Perdata, objek perjanjian merupakan salah satu syarat sahnya perjanjian. Objek perjanjian ini sendiri, nantinya akan menjadi dasar para pihak dalam pelaksanaan prestasi. Objek suatu perjanjian harus memenuhi beberapa persyaratan, yaitu objeknya harus dapat ditentukan, diperbolehkan menurut undang-undang yang berlaku, dan tidak bertentangan dengan asusila. (Kartini Muljadi, 2014: 91). Pada perjanjian yang penulis teliti, objek perjanjian yang dimaksud adalah Utang-Piutang. Menurut Hukum Perjanjian, bentuk perjanjian itu sendiri memiliki beberapa bentuk: (Salim, 2008: 42-43).

1) Perjanjian bawah tangan, perjanjian yang ditandatangani oleh para pihak yang bersangkutan. Perjanjian yang hanya mengikat para pihak yang ada dalam perjanjian, tetapi tidak mempunyai kekuatan mengikat para pihak.

2) Perjanjian yang disaksikan di hadapan notaris, keberadaan notaris disini hanya untuk melegalisir tanda tangan para pihak. Fungsi kesaksian notaris semata-mata hanya untuk melegalisir kebenaran tanda tangan para pihak.

3) Perjanjian dalam bentuk Akta Notariel, merupakan akta yang dibuat di hadapan dan di muka pejabat yang berwenang untuk itu. Fungsi dari akta notarial ini adalah sebagai bukti bahwa para pihak telah melaksanakan perjanjian tertentu, sebagai tujuan dan keinginan para pihak.

Pada perjanjian yang penulis teliti, termasuk dalam bentuk perjanjian bawah tangan karena hanya dibuat oleh para pihak tanpa adanya campur tangan dari pihak ketiga.

Pada perjanjian hutang piutang yang dibuat oleh para pihak, untuk mengurangi resiko debitor wanprestasi dalam hal ini tidak melaksanakan kewajiban melakukan pelunasan hutang. Maka, pihak pertama memberikan jaminan atas sebidang tanah atas nama Pihak Pertama sebagai jaminan utang pada perjanjian. Namun dalam hal ini, jaminan atas tanah tersebut tidak diikat dengan hak tanggungan yang apabila sebidang tanah diikat dengan hak tanggungan dan ditemukan keadaan debitur wanprestasi, kreditur dapat langsung melakukan lelang atas tanah tersebut dan mengambil pelunasan atas hutang.

Sebelumnya penulis telah melakukan penelitian terhadap kasus tersebut sebagaimana, Pihak Pertama meminjam uang sebesar Rp100.000.000,- kepada Pihak Kedua pada awal bulan Februari 2015. Cicilan pelunasan hutang sebesar Rp5.000.000,- yang dibayarkan maksimal minggu ke-4 setiap bulannya. Permasalahan mulai muncul sejak memasuki angsuran ke-13 yaitu debitor tidak membayarkan jumlah nominal sesuai yang diperjanjikan, seharusnya sejumlah Rp5.000.000,berkurang menjadi Rp3.000.000,- dan saat memasuki angsuran ke-14 dan 15, debitor tidak membayarkan pelunasan hutang sama sekali pada kreditor atau dapat dikatakan pembayaran menunggak 2 (Dua) bulan. Kreditor pada saat itu juga telah melakukan somasi pada debitor sebanyak 2 (Dua) kali yang isinya berupa teguran untuk segera melakukan pelunasan hutang tersebut. Setelah adanya somasi tersebut, kreditor juga tidak segera melakukan pelunasan hutang hingga pada akhirnya debitor melakukan permohonan eksekusi atas tanah yang digunakan sebagai jaminan tersebut ke Pengadilan Negeri Purwokerto. Namun, permohonan eksekusi tersebut ditolak karena kreditor tidak memegang Sertifikat Hak Tanggungan.

Berikut, rincian pelunasan hutang yang telah debitor bayar hingga bulan ke-12:

\begin{tabular}{|c|c|c|c|c|}
\hline Angsuran & Sisa Hutang & & Jominal & $\begin{array}{c}\text { Tanggal } \\
\text { Pembayaran }\end{array}$ \\
\hline 0 & Rp 100.000.000,- & & & \\
\hline 1 & Rp $\quad 95.000 .000,-$ & $\mathrm{Rp}$ & 5.000.000,- & 21 Maret 2015 \\
\hline 2 & Rp $\quad 90.000 .000,-$ & Rp & $5.000 .000,-$ & 24 April 2015 \\
\hline 3 & Rp $\quad 85.000 .000,-$ & $\mathrm{Rp}$ & $5.000 .000,-$ & 27 Mei 2015 \\
\hline 4 & $80.000 .000,-$ & $\mathrm{Rp}$ & $5.000 .000,-$ & 29 Juni 2015 \\
\hline
\end{tabular}




\begin{tabular}{|c|c|c|c|c|c|}
\hline Angsuran & \multicolumn{2}{|c|}{ Sisa Hutang } & \multicolumn{2}{|c|}{ Nominal } & $\begin{array}{c}\text { Tanggal } \\
\text { Pembayaran }\end{array}$ \\
\hline 5 & $\mathrm{Rp}$ & 75.000.000,- & Rp & $5.000 .000,-$ & 22 July 2015 \\
\hline 6 & $\mathrm{Rp}$ & 70.000.000,- & $\mathrm{Rp}$ & $5.000 .000,-$ & 19 Agustus 2015 \\
\hline 7 & $\mathrm{Rp}$ & $65.000 .000,-$ & $\mathrm{Rp}$ & $5.000 .000,-$ & 23 September 2015 \\
\hline 8 & $\mathrm{Rp}$ & $60.000 .000,-$ & Rp & $5.000 .000,-$ & 21 Oktober 2015 \\
\hline 9 & $\mathrm{Rp}$ & $55.000 .000,-$ & Rp & $5.000 .000,-$ & 25 November 2015 \\
\hline 10 & $\mathrm{Rp}$ & $50.000 .000,-$ & $\mathrm{Rp}$ & $5.000 .000,-$ & 25 Desember 2015 \\
\hline 11 & $\mathrm{Rp}$ & $45.000 .000,-$ & Rp & $5.000 .000,-$ & 20 Januari 2016 \\
\hline 12 & $\mathrm{Rp}$ & $40.000 .000,-$ & Rp & $5.000 .000,-$ & 28 Februari 2016 \\
\hline 13 & $\mathrm{Rp}$ & 37.000.000,-- & $\mathrm{Rp}$ & $3.000 .000,-$ & 30 Maret 2016 \\
\hline
\end{tabular}

Dari kasus tersebut di atas, perlindungan hukum bagi kreditor atas jaminan tanah yang tidak didaftarkan sebagai hak tanggungan ini, apabila dilihat dari objek jaminannya yaitu Tanah dan apabila dilihat dari sudut pandang yuridis hak tanggungan tanah yang tidak didaftarkan sebagai hak tanggungan ini tidak memiiki perlindungan hukum bagi kreditornya. Kreditor yang memperoleh perlindungan hukum hanyalah kreditor pemegang Sertifikat Hak Tanggungan(SHT). Pada UUHT ini juga tidak mengatur pada tanah yang tidak didaftarkan sebagai Hak Tanggungan. Maka, penulis berpendapat bahwa jaminan hak atas tanah ini tidak bisa dijadikan sebagai jaminan pelunasan hutang, karena tidak didaftarkan sebagai Hak Tanggungan maka otomatis tanah yang dijadikan sebagai jaminan tidak memiliki keistimewaan seperti tanah yang didaftarkan sebagai hak tanggungan. Salah satunya juga tidak berlaku asas droit de suite, Pasal 7 UUHT menyebutkan bahwa:

Benda yang dijadikan hak tanggungan akan tetap mengikuti objeknya dalam tangan siapapun objek benda tersebut berada.

Walaupun objek hak tanggungan sudah berpindah tangan dan menjadi milik dari pihak lain, kreditur masih tetap dapat menggunakan haknya melakukan eksekusi jika debitur wanprestasi. Pengikatan benda sebagai objek hak tangungan, maka hak tanggungan secara kekuasaan telah beralih dari tangan debitur pemilik objek hak tanggungan kepada kreditur sebagai pemegang hak tanggungan. (Dian Pertiwi, 2013: 6). Menurut penulis, ini merupakan salah satu bentuk perlindungan hukum yang diberikan pada seorang debitor pemegang hak tanggungan oleh UUHT itu sendiri. Namun, asas ini tidak berlaku bagi kreditor pada kasus yang penulis teliti karena kreditor bukan pemegang hak tanggungan.

Jaminan sebenarnya sebagai salah satu bentuk perlindungan hukum secara preventif, artinya jaminan digunakan untuk berjaga-jaga sebelum debitor dalam hal ini melakukan wanprestasi atau sebelum timbulnya sengketa. Namun, pada perjanjian utang- piutang ini menurut penulis jaminan atas tanah tersebut tidak bisa digunakan sebagai pelunasan hutang. Maka, perlindungan hukum yang dapat diberikan kepada kreditor adalah dengan mengacu pada Pasal 1131 KUHPerdata:

Segala barang-barang bergerak dan tidak bergerak milik debitur, baik yang sudah ada maupun yang akan ada, menjadi jaminan untuk perikatan-perikatan perorangan debitur itu.

Selanjutnya dasar jaminan umum dilanjutkan dengan Pasal 1132 KUHPerdata:

Barang-barang itu menjadi jaminan bersama bagi semua kreditur terhadapnya hasil penjualan barang-barang itu dibagi menurut perbandingan piutang masing-masing kecuali bila diantara para kreditur itu ada alasan-alasan sah untuk didahulukan. 
Berdasarkan ketentuan dalam Pasal 1131 dan 1132 KUHPerdata, jaminan yang bersifat umum ditunjukan kepada seluruh kreditur dan mengenai segala kebendaan debitur. Guna pelunasan hutang debitor, dari pasal ini dapat dipahami bahwa kreditor bisa melakukan pelelangan atas seluruh kekayaan debitor dan mengambil pelunasan hutang dari penjualan harta tersebut. Namun, menurut penulis tanah dikecualikan terhadap pelelangan umum. Hal ini karena, tanah yang bisa dilakukan pelelangan umum adalah tanah yang telah didaftarkan sebagai Hak Tanggungan. Sebagaimana ketentuan umum dan Pasal 6 dalam UUHT menyebutkan bahwa:

Ketetentuan umum,

Hak Tanggungan adalah hak jaminan atas tanah untuk pelunasan utang tertentu, yang mempunyai kedudukan diutamakan kepada kreditor tertentu terhadap kreditor-kreditor lain. Dalam arti, bahwa jika debitor cidera janji, kreditor pemegang Hak Tanggungan berhak menjual pelelangan umum tanah yang dijadikan jaminan menurut ketentuan peraturan perundang-undangan yang bersangkutan, dengan hak mendahului daripada kreditorkreditor lain. Kedudukan diutamakan tersebut sudah barang tentu tidak mengurangi preferensi piutang- piutang Negara menurut ketentuan-ketentuan hukum yang berlaku.

Pasal 6

Apabila debitor cidera janji, pemegang Hak Tanggungan pertama mempunyai hak untuk menjual objek Hak Tanggungan atas kekuasaan sendiri melalui pelelangan umum serta mengambil pelunasan piutangnya dari hasil penjualan tersebut.

Dari kedua pasal ini, telah menyebutkan secara jelas apabila tanah yang dapat dilelang adalah tanah yang terikat oleh Hak Tanggungan dan hanya kreditur pemegang Hak Tanggungan yang dapat menjual tanah tersebut melalui pelelangan umum.

Jaminan secara umum yang diatur dalam Pasal 1131 KUHPerdata menjelaskan bahwa seluruh kekayaan debitor baik meliputi benda bergerak maupun benda tetap, baik yang ada pada saat perjanjian utang piutang maupun yang akan timbul seluruhnya dijadikan sebagai barang jaminan. J. Satrio menuliskan dalam bukunya, bahwa dari Pasal 1131 KUHPerdata dapat disimpulkan point sebagai berikut:

a. Seorang kreditor boleh mengambil pelunasan hutang dari harta kekayaan debitor;

b. Setiap kekayaan debitor dapat dijual guna pelunasan tagihan kreditor;

c. Hak tagihan kreditor hanya dijamin dengan harta benda debitor saja, tidak dengan "person debitor". (Niken Prasetyawati, 2015: 125)

Namun, masyarakat menganggap bahwa Pasal 1131 sebagai jaminan umum ini memiliki kekurangan. Hal ini dikarenakan: (Munir Fuady, 2013: 8-9)

1. Benda tidak khusus, pasal ini tidak menyebutkan benda apa saja yang dapat dijadikan sebagai jaminan utang.

2. Jaminan tidak mengikuti benda, apabila jaminan atau benda dialihkan kepada pihak lain oleh debitor, maka hak kreditor tetap melekat pada benda tersebut tanpa melihat ditangan siapa benda itu berada.

3. Tidak ada kedudukan bagi kreditur preference, berbeda dengan jaminan umum dari Pasal tersebut. Kreditor tidak dapat diberi kedudukan yang didahulukan dalam pelunasan hutang apabila debitor wanprestasi.

Menurut penulis, penggunaan jaminan umum sebagai jaminan utang sebenarnya sudah otomatis akan ada ketika perjanjian itu timbul bahkan tanpa para pihak mencantumkan klausula jaminan dalam perjanjian. Tetapai, dilihat dari kekurangan jaminan kebendaan secara umum, maka masyarakat pada umumnya memilih jaminan secara khusus terhadap suatu benda yang akan dijadikan sebagai barang jaminan. Misalnya seperti, jaminan benda bergerak yaitu fidusia, 
gadai, jaminan benda tetap yaitu hak tanggungan. Pada kasus ini, karena jaminan khusus yang diberikan debitor berupa jaminan atas tanah ini tidak didaftarkan sebagai Hak Tanggungan dan tidak bisa dilakukan eksekusi melalui pelelangan umum maka, penulis berpendapat bahwa jaminan yang dapat digunakan sebagai bentuk pengganti dari jaminan atas tanah tersebut adalah seluruh harta kekayaan debitor baik benda bergerak maupun tidak bergerak sesuai dengan Pasal 1131 KUHPerdata. Inilah yang kemudian penulis simpulkan, bahwa perlindungan hukum secara preventif bagi debitor atas tanah yang tidak didaftarkan sebagai hak tanggungan melalui Pasal 1131, seluruh harta kekayaan debitor yang dijadikan sebagai jaminan utang dan dilakukan pelelangan umum, karena jaminan atas tanah yang ada dalam perjanjian utang piutang tersebut tidak bisa dijadikan jaminan.

Hukum bukan hanya memperhatikan kepentingan kreditur. Perlindungan juga diberikan kepada debitur dan pemegang Hak Tanggungan.

Tanah yang merupakan bisa dijadikan sebagai jaminan kebendaan, yaitu jaminan yang diberikan atas suatu barang. Namun, hanya tanah yang didaftarkan sebagai Hak Tanggungan dan mempunyai Sertifikat Hak Tanggungan saja tanah yang dapat dilakukan eksekusi melalui pelelangan umum dan hanya kepada kreditor pemegang Sertifikat Hak Tanggungan saja yang dapat melakukan pelelangan atas tanah tersebut. Selain daripada hal tersebut, kreditor tidak memiliki perlindungan hukum.

\section{Simpulan}

Perlindungan hukum bagi kreditor atas jaminan tanah yang tidak didaftarkan sebagai hak tanggungan ini kembali merujuk pada Pasal 1131 KUHPerdata, hal ini karena jaminan atas tanah yang digunakan sebagai jaminan tidak bisa dilakukan eksekusi langsung (parate eksekusi) melalui pelelangan umum karena tidak didaftarkan sebagai hak tanggungan dan kreditur tidak memegang Sertifikat Hak Tanggungan. Jaminan kebendaan juga tidak bisa diberikan atas tanah tersebut. Maka, jaminan yang digunakan dalam perjanjian utang-piutang ini adalah seluruh kekayaan debitor baik benda bergerak maupun tidak bergerak. Hal ini terjadi juga karena kelalaian kreditur, yang tidak meminta pendaftaran atas jaminan atas tanah tersebut sebagai Hak Tanggungan. Apabila jaminan tanah tersebut didaftarkan sebagai Hak Tanggungan, maka kreditur akan mendapatkan perlindungan hukum sebagai kreditur preference dan keistimewaan lain sebagaimana yang ada dalam Undang-Undang Hak Tanggungan.

\section{E. Saran}

Bagi para pihak, apabila membuat perjanjian baik dengan jaminan atau tidak alangkah lebih aman ketika dihadapan PPAT/Notaris karena nanti akan timbul akta perjanjian dari notaris yang kemudian apabila terjadi sengketa bisa digunakan sebagai alat bukti yang kuat dan mengikat melebihi akta bawah tangan. Apabila hendak menjadikan tanah dijadikan sebagai jaminan atas hutang, lebih baik jika didaftarkan sebagai Hak Tanggungan.

\section{F. Daftar Pustaka}

\section{Buku}

Ignatius Ridwan. 1996. Hak Tanggungan Atas Tanah. Semarang: Badan Penerbit Universitas Diponegoro

J. Satrio. 2002. Aspek-aspek Hukum Perkreditan pada Bank. Jakarta: Alfabeta.

Kartini Muljadi. 2014. Perikatan yang Lahir dari Perjanjian. 6 ed. Jakarta: Rajawali Pers. Munir Fuady. 2013. Hukum Jaminan Utang. Jakarta: PT Gelora Aksara Pratama.

Peter Mahmud Marzuki. 2017. Penelitian Hukum. Jakarta: Kencana Prenada Media. 
Philipus M. Hadjon, 1987. Perlindungan Hukum bagi Rakyat Indonesia. - ed. Surabaya: PT Bina IImu.

Rosnindar Sembiring. 2016. Hukum Keluarga (Harta-Harta Benda dalam Perkawinan). - ed. Jakarta: Raja Grafindo Persada.

Salim, 2008. Hukum Perjanjian, Teori dan Praktik Penyusunan Perjanjian. 5 ed. Jakarta: Sinar Grafika.

\section{Jurnal Nasional}

Dian Pertiwi. 2013. "Perlindungan Hukum Pemegang Hak Tanggungan yang Objeknya Dikuasai Pihak Ketiga Berdasarkan Perjanjian Sewa Menyewa”. Calyptra: Jurnal IImiah Mahasiswa Vol. 2 No.2 UBAYA. Surabaya: Fakultas Hukum UBAYA

Lidya Mahendra. 2016. "Perlindungan Hak-Hak Kreditur dalam Hal Adanya Pengalihan Benda Jaminan oleh Pihak Debitur". Jurnal IImiah Prodi Magister Kenotariatan Acta Comitas ISSN: 2502-89601 e-ISSN: 2502-7573. Volume 2. Bali: Fakultas Hukum UDAYANA

Luthfi Febrika Nola. 2016. "Upaya Perlindungan Hukum Secara Terpadu bagi Tenaga Kerja Indonesia (TKI)". Jurnal Negara Hukum Vol. 7 No. 1. Jakarta: Pusat Penelitian Badan Keahlian DPR RI.

Niken Prasetyawati. 2015. “Jaminan Kebendaan dan Jaminan Perorangan Sebagai Upaya Perlindungan Hukum bagi Pemilik Piutang". Jurnal Sosial Humaniora Vol. 8 No. 1. Surabaya: IPTEK ITS

Saraswati. 2018. "Pelaksanaan Pendaftaran Hak Tanggungan Sebagai Implementasi Asas Publisitas dalam Hak Tanggungan". Jurnal ePrints UMS. Surakarta: Fakultas Hukum UMS.

\section{Internet}

Tampubolon. 2019. Prosedur Pembebanan Hak Tanggungan Atas Tanah. https://konsultanhukum.web. id/prosedur-pembebanan-hak-tanggungan-hak-atas- tanah/.Diakses pada tanggal 30 September 2019. 